\title{
The final judgment in African
}

\section{perspectives}

\author{
I W C van Wyk (The Africa Institute for Missiology) ${ }^{1}$ \\ Reformed Theological College \\ University of Pretoria
}

\begin{abstract}
African churches show little interest in the notion of the final judgment. Various reasons for the lack of interest in this important aspect of biblical faith are discussed. Special attention is given to the problems of time and history as they manifest in African thinking. The idea of punishment as it is perceived in Africa also receives attention. The article looks at the biblical texts on the final judgment from an African perspective. African philosophy and spirituality facilitate a rediscovery of the joyful dimensions of this notion. One of the main arguments is that Africa should not experience insurmountable problems in embracing this aspect of the gospel. On the contrary: Africa can assist the ecumenical world to discover aspects of this message not yet disclosed. The article concludes with a discussion on the fate of the African ancestors.
\end{abstract}

\section{INTRODUCTION}

The notion of the "final judgment" or the "last judgment" is an important aspect of the biblical message. ${ }^{2}$ For centuries this aspect of the gospel has been at the centre of theology and church life. The countless paintings originating from the Middle Ages and Counter-Reformation which have this subject as theme, are testimony to this. Michelangelo's famous fresco depicting the last judgment, painted in the Sistine Chapel at the Vatican between 1536 and 1541, serves as a good example. At the same time Luther's theology, which could be seen as a serious struggle with the "dear latest day" (Peters 1967; Lohse 1995:345; Bayer 2003:297-304) also comes to mind.

In the declining Christendom of the Western world (or Northern Christianity, to use a better term) this notion has, however, become one of the

\footnotetext{
${ }^{1}$ In a previous article (Van Wyk 1996) on the "final judgement", I argued that we have a duty towards Africa to reflect on this subject from African perspectives. This article is in fulfillment of that duty I have taken upon myself.

${ }^{2}$ I am referring to both the New Testament and Old Testament (see Kaiser 2003:308-342 for the theology of the Old Testament).
} 
obstacles to faith for non-religious ${ }^{3}$ and religious people alike. Over the past few decades many church members and theologians ${ }^{4}$ have expressed their opposition to this notion (cf Van Wyk 1996:506-526; Miggelbrink 2002:9-11; 124-134). The following quotation by Richard Niebuhr (1959:193) about nineteenth-century American liberalism, captivates the dilemma of Northern Christianity: “... a God without wrath brought men without sin into a kingdom without judgment through the ministrations of a Christ without a cross ...."

In the growing African Christendom, this notion is not a high priority in debate either. The reasons are, however, very different to the reasons encountered in the North. There appears not to be a tradition of referring to God's judgment - at least not a judgment at or after death. ${ }^{5}$ In view of the fact that this notion is a central theme in the Bible, we must jointly come up with a way of making it intelligible to the ever-growing church in Africa. We should consider arguments that would enable us to make a positive contribution in this regard.

\section{THE ABSENCE OF THE NOTION OF JUDGMENT IN AFRICA}

\subsection{African Traditional Religion ${ }^{6}$}

Traditional Africans believe in a life after death for their ancestors, but are not aware of rewards or punishment in the afterlife (Mbiti 1975a:259-262;

1985:161; Sundermeier 1990:154; Hammond-Tooke 1993:149). Theo Sundermeier (1990:154, 201), however, notes two exceptions. The Koko and Basa peoples of Cameroon believe that evil people are destined for a cold place and good people for a place full of light. In view of the fact that they also

\footnotetext{
${ }^{3}$ It would, however, appear as if many fundamentalists (cf Kato 1975:77-90) and "charismatic sects" are not affected by the crisis (cf Heyer 1999).

${ }^{4}$ During the past decade, a number of German theologians gave attention to this theme (cf Sauter 2004 for an overview of recent publications).

${ }^{5}$ Why there is no such tradition in Africa, still needs to be established. In European theology this notion disappeared in the wake of the dominance of the idea of evolution, linked to development and progress. In other words: It had to do with the image of history. In a world of unending optimism there is no room for a catastrophic end (Berdiajew 1930:348-374). In Africa it might be a matter of the people not understanding history in terms of progress or of a beginning and an end. If nothing else is expected in and of history, then a final event as such is not of relevance.

${ }^{6}$ Many people would prefer the reference "African Indigenous Religions". I decided to use the known term.
} 
believe that the repenters are destined for an intermediate state of existence, ${ }^{7}$ the originality of their beliefs is, however, doubtful.The Akan people of Ghana (according to Sundermeier) is the other exception. They believe in reward and punishment after life. The rest of Africa believes in a God that judges and punishes evildoers in the here and now during their earthly life, but not after death. John Mbiti (1975a:259-262; 1985:161) also refers to some exceptions to the rule. In this regard he mentions the Yoruba who believe in a judgment after death, based on earthly morality and the Lodagaa who fear punishment of evil by the ancestors after death. He also refers to, the Lozi who believe that eternal life (or life with the ancestors) will only be granted when people could identify themselves to the ancestors through tribal marks on their arms. Therefore, as far as we know this epithet of God is, apart from these exceptions, unknown to traditional Africa. Steve Biko (2004:49) affirms this when he, as a Christian traditionalist, states:

\begin{abstract}
We believed - and this was consistent with our views of life - that all people who died had a special place next to God. We felt that a communication with God could only be through these people. We never knew anything about hell - we do not believe that God can create people only to punish them eternally after a short period on earth ... It was the missionaries who confused our people with their religion. They ... preach a theology of the existence of hell, scaring our fathers and mothers with stories about burning in eternal flames and gnashing of teeth and grinding of bone. This cold cruel religion was strange to us but our fore-fathers [sic!] were sufficiently scared of the unknown impending anger to believe that it was worth a try. Down went our cultural values!
\end{abstract}

\title{
2.2 African Christianity
}

African Christianity has difficulty in positively relating to the notion of the final judgment. It is confirmed by my research undertaken within the Hervormde Kerk in Suidelike Afrika (HKSA) ${ }^{9}$ According to the ministers and theological

\footnotetext{
${ }^{7}$ The Roman Catholic influence is clear.

${ }^{9}$ Thirteen ministers of the HKSA who attended the Continuing Theological Training (CTT) held at Hammanskraal on 19 November-2003 and 16 who attended the CTT at Dududu on 8 July-2004 completed a questionnaire with five questions on the final judgment. Sixteen students of the Africa Institute for Missiology (AIM) completed a similar questionnaire between 2003 and 2004. Furthermore, twelve students who attended the lectures on Eschatology in 2003 and 2004 provided me with information relating to the subject.
} 
students of the HKSA, the problem with the final or last judgment starts with the fact that most African Christians have a dual religiosity. The vast majority are namely traditionalists and Christians at the same time. Because the idea of a last judgment is largely unknown to African Traditional Religion (ATR), Christians tend to follow their traditional lifestyle and simply ignore this notion. Interestingly though, many ministers regularly preach about the theme. They however complain that the congregants have difficulty in making sense of this theme. Many cannot reconcile the idea of punishment with the creator, whom they know as the God of love. ${ }^{10}$

African Christians are comfortable to live with the jubilant expectation of being re-united with their ancestors after death and simply ignore the biblical reports on the promise of a judgment at or after death. They see the coming of Christ as an event of rejoicing and dancing and not one of rejection and tears. It therefore comes as no surprise that Africans, in some of their choruses or hymns, confess their belief in the eschatological Jesus, who will not come to judge, but to sing and dance with them. One such example is quoted hereunder, courtesy of Maluleke's (1997:192, 201 translation):

One of these days, the Lord Jesus will return

We will sing, oh yes, we will sing with Jesus.

We will clap our hands, oh yes; we will clap our hands with Jesus.

We will dance around happily with Jesus.

Others will grumble and grumble and grumble.

Others will look on with envy and burning jealousy.

Another reason why this notion is irrelevant to African Christians lies in the inseparable unity of the last judgment with the second coming of Christ. They believe in that which they can see. They also believe in that which has meaning to them here and now. A vague idea about something somewhere in the future, does not appeal to them. They also find the idea that Jesus will appear again "at the end of times" strange, because they do not believe that life will end and that life on earth will have a final moment.. A fourth reason is that Africans do not value the concept of "sin", and since the notions of the "final judgment" and "sin" are inseparable, the former would remain unintelligible to the African mind. A fifth reason is that the human race will be

\footnotetext{
${ }^{10}$ I suspect the fear for the final judgment has to do with the understanding of God's judgment as fatum/tragedy. When theologians identify big historical catastrophes with God's judgment in the sense of a mere fatum, then people tend to reject this notion. When people such as Werner Elert thus explained the First World War (cf Etzelmüller 2005:261-263) Germans developed a certain aversion in this regard. Africans fear this notion because of the possibility that theologians wouldl identify the AIDS pandemic with God's judgement as a blind fatum.
} 
divided into "sheep and goats" at the final judgment. As religions of integration and reconciliation African Traditional Religion, as well as African Christianity, will therefore - in principle - have difficulties with such notion. A sixth reason is related to the issue concerning the fate of people who belong(ed) to the Traditional Religions. Lastly, as Biko has mentioned, Africans find the idea of "eternal punishment" unacceptable.

My approach to these issues is to uncover the unfairness of the critique, to disclose false theological presumptions and to convince sceptics that for African Christianity, this notion has a positive meaning.

\section{THE FINAL JUDGMENT IN AFRICAN TERMS}

\subsection{Punishment and judgment in Africa}

In our attempt to make this notion intelligible to Africans, we should start with the concepts of punishment and judgment themselves. Biko's statement that he finds the idea of a punishing God unacceptable, again comes to mind. ${ }^{11}$ Contrary to Biko, there is no doubt in my mind that "punishment" and "judgment" are well-known and acceptable elements of social and religious life in Africa. Traditionalists and Christians alike regard punishment as an important aspect of religion. The majority of those questioned, believe that the ancestors and God punish people for a variety of reasons - sometimes even in a very harsh way. The idea of punishment from "higher powers" thus forms part of the religious framework in Africa.

Pre-modern village societies, as well as modern township communities know that people can only live together in harmony when they punish transgressors of family and community rules. Discipline and punishment are accepted educational methods among Africans. Most of the time, Africans make limited use of corporal punishment. They, however, regard other forms of punishment as necessary for the proper upbringing of a child. They also know that the functioning of "common law" is necessary to uphold public order. Strategies such as the intimidation of people through public opinion and public mockery, as well as isolation, excommunication and deportation, all contribute towards the enforcement of the accepted morality. In the case of severe offences such as theft, witchcraft and adultery, the ius talionis would be replaced by institutionalised courts to satisfy their need for retribution.

\footnotetext{
${ }^{11}$ To European theology this critique is well-known. Friedrich Nietzsche led us on a path of discussion that forces us to defend the intelligibleness of a wrathful God in modern society. Recently, theologians have tried to explain why love cannot be understood without punishment (cf Stümke 1996).
} 
Should the courts not reach a verdict, they could even implore God's judgment. For example, the accused can be forced to drink poison or to walk on fire. Should he survive, it would serve as a sign of his innocence. Should he succumb, the community would have the satisfaction that a transgression was rightfully punished by God.

Most African societies regard their social morality as a gift from their ancestors. They believe their progenitors passed a good lifestyle, taboos as well as rules and regulations for the community on to them. As the "livingdead", they also guard over this morality. They punish those who do not respect the accepted morality by bringing all kinds of calamities and misfortunes onto them (some scholars believe punishment from the ancestors is never harsh and only has educational value). Be that as it may, they punish the offenders (Sundermeier 1990:153). Punishment from the ancestors ensures that members of the family and tribe respect and abide by the ethical norms that they (the ancestors) have left behind. Even in this religion of grace (Gnadenreligion) there is room for the wrath of the ancestors, who would punish those who do not respect the ancestors and their legacy (Sundermeier 1990:148-154, 213-221; Hammond-Tooke 1993:149-197; Obengo 1997:5961; Magesa 1998:44-81, 145-176; Kwenda 1999:8-11; Müller \& Ritz-Müller 1999:106-107).

Most Africans do not have a problem of associating God and punishment with one another (Mbiti 1975b:46). Some polytheistic African tribes even believe in punishing gods. Shango, the Yoruba of Nigeria's god of lightning, who punishes thieves through lightning - the "bad death", is a good example of a punishing god in Africa (Müller \& Ritz-Müller 1999:114-119). Because most African Traditional Religions are monotheistic in nature, the peoples who belong to these religions believe that the wrathful God is none other than the creator-God. They believe that God must react to unacceptable human behavior. Because the ultimate power is His, and because He is the final guardian of morality and law, He can and must punish people, sometimes through sickness and other calamities such as droughts in extreme cases. He can even punish an entire tribe because of the transgression of an individual like the king. Despite his willingness to punish, he is never without mercy. The aim of his punishment is always healing - the healing of relationships among people and between himself and his people. His judgments are always conciliatory and therapeutic in nature (Magesa 1998:44, 172-275).

Since punishment and judgment are well-known concepts in Africa, the biblical image of the God of love who punishes sin and evil should not be an insurmountable problem to the African mind. We can therefore move to the problem of eschatology and concentrate on the problems of time and history. 


\title{
3.2 Eschatology
}

\subsubsection{The final judgment and the problem of time and history}

It is generally accepted that Africans look backwards to the past and not forward to the future. John Mbiti (1978:24-32; 1985:15-28) is mainly responsible for this opinion:

\begin{abstract}
In traditional African thought, there is no concept of history moving 'forward' towards a future climax, or towards an end of the world. Since the future does not exist beyond a few months, the future cannot expect to usher in a golden age, or a radically different state of affairs from what is in the Sasa and the Zamani. The notion of a messianic hope, or a final destruction of the world, has no place in traditional concept of history. So African peoples have no 'belief in progress', the idea that the development of human activities and achievements move from a low o a higher degree. The people neither plan for the distant future nor "build castles in the air".
\end{abstract}

(Mbiti 1985:23)

Many writers (such as Nyirongo 1997:89-98; Van Rooy 1999:248; Van der Walt 2003:161-175) agree with Mbiti by arguing that Africans live for the immediate present and therefore are not interested in the consequences their actions hold for tomorrow and the distant future. The question is whether the so-called lack of future-orientation provides an explanation for the disinterest in the final judgment. I would be reluctant to accept such a theory. Two arguments hold the key which reveals the contrary: Firstly, sufficient proof that Africans are future-orientated people exists. Secondly, the biblical message about the final judgment is not (only) a message about an event in the distant future, but is also a message about the present life.

\subsubsection{Africa and the "future"}

Through contact with my students I have become convinced that the theory that Africans are not future-orientated people, is questionable. By looking at well-known proverbs and idiomatic expressions used in South Africa, it becomes clear that Mbiti's theory is not correct.

Expressions such as: Ha re di tlohele di hole mmoho, re tla di bona motlha tsatsi la kotulo - Let us leave things today as they are; we will see in 
future how they turned out ${ }^{12}$ can easily mislead one into believing that Africans are fatalistic by nature. The following expressions, however, indicate the contrary: Sejamonna ha se mo gete - A person always has hope to succeed in future (translated from Setswana by N Mokoena). Africans know they should plan and work for a better future, as the following expressions indicate: Moleta ngwedi ke moleta lefifi - Don't stick to one plan, you should always have another one (translated from Setswana by $\mathrm{H}$ Msiza), Ditlamelwana tsa pula di baakangwa go sa le gale - Because the future is uncertain, you should start preparing for it now (translated from Setswana by M Moaisi), Africa tsoha uyeketsetse. Ushebile banna abasebetsa uphuthile matsoho tsoha uyeketsetse - Africa, you should not fold your arms whilst other people are working. You should stand up and do something for your family and your nation! (translated from South Sotho by S. Tshabalala) and Uli bambe li nga shone - Make haste while the sun shines (translated from Zulu by $\mathrm{H}$ Msiza). The Zulus also have a saying: Inbila yaswela umsila ngokulayezela - If you want something for tomorrow, you must work for it today (translated from Zulu by S Tshabalala).

Education is only meaningful when it prepares children for the future. The Zulus therefore say: Uthingo lugotshwa lusemanzi - One starts with education today for the life of tomorrow (translated by S Dlamini). In Africa education consummates in upholding good relationships with others. Because they know the future is full of uncertainty they teach their children to uphold good relationships. Therefore the teaching goes: Shago la hloka thobela ke mojato - Do not be ungrateful! If you have something now, share it with others. Tomorrow they will help you when you are in need (translated from Sepedi by L Maenetsa); and O seke wa nyela didiba - Don't treat people bad today; tomorrow you will need them (translated from South Sotho by D Mphahlela)

Africans do not only know how to plan for the future, but also know that thrift and frugality (claimed to be some of the virtues underlying the success of the capitalists in the Calvinistic regions) are important for a secure economic position in future, hence the sayings: Mpa ke ngwana e a beelwa - When you have something to eat today, you should keep enough for tomorrow (translated from Setswana by M Moaisi); Phiri o rile a bose gangwe - Don't eat everything that you have now. Think about tomorrow! (translated from Sepedi by L Maenetsa); Mayidle izishiyele - The king can eat now, but he should also think about tomorrow (translated from Xhosa by B Mbutsi); Umzingisi akanashwa - The one who preserves now, will not be disappointed in future (translated from Xhosa by B Mbutsi).

${ }^{12}$ Translated from South Sotho by D Mphahlela. 
Furthermore, Mbiti's arguments with regard to Africans' perceived lack of future-orientation, have to be rejected when considering some of the rituals regularly performed in this country.

Name-giving rituals are common among Africans. At these big family feasts, people expect the ancestors to bless the child to ensure a bright future for the child. Many names that parents give to their children are indicative of the family's hope for their children in the future. For instance, if it is their hope for a girl to become a good leader, they would name her "queen". Initiation rituals also serve as important indicators of African peoples' future-orientation. The Xhosa rituals, for example, are symbolic of youngsters who left their childhood behind them and now show a willingness to accept the future responsibilities of adults. The payment of lobola before death is an important eschatological act. A person who lived with a woman without complying with his moral and financial duties will not enjoy a peaceful afterlife. Polygyny is not only an institution that has to do with sexuality, marriage and family life, but also has to do with future economic security. By marrying many wives a man would have many daughters, which will yield many heads of cattle paid to him as part of lobola, which in turn would ensure him of a carefree old age. Many funeral rituals (such as the one that has to do with the return of the spirit of a student or migrant worker to their homestead) are performed before death so that the uncertain future does not catch people off guard. Harvest rituals among the Zulu provide a clear indication that they are future-orientated. The fact that they store their grain in the izinqolobane is proof of them planning and living with the future in mind.

To conclude: Africans (like all other people) are future-orientated. At the same time, they are also inclined to take notice of the past. Like all other people, they also live for today. The important fact, however, is that Africans are also looking at the future, plan for the future and expect certain things to happen in the future. Therefore, the argument that they neglect the last judgment because they are not future-orientated, is clearly without any substance.

\subsubsection{The presence of the final judgment}

Joseph Donders (1985:51-56) blames Christianity for the moral decay in Africa. According to him, the message of "heaven" or "eternal salvation" deludes people into indifference towards their earthly responsibilities. The message of the "last judgment" in particular confuses people as far as their moral duties are concerned. In traditional Africa, the authorities punished people immediately after transgressions. This practice created moral certainty, stability and security. The message of the "last judgment" misleads people 
into thinking that because there is no need fearing immediate punishment, one could do wrong in the present. The only way to moral regeneration in Africa therefore is by rejecting the eschatological message of the New Testament and by returning to a religious system in terms of which the community immediately punishes people for transgressions according to the community's familiar moral principles handed down to them by their ancestors.

In defence of the New Testament message, I wish to state that the adjective "last" judgment is unfortunate. The reference "final" judgment is closer to the biblical message. When dealing with biblical eschatology, we should not think in terms of a "lineal history". The biblical view of eschatology is far more complex than the Western "lineal" concept of time. In the New Testament, the "last things" could also pertain to things in the present moment and not only to the distant future. According to the Bible the "final" judgment should not only be understood and explained in terms of an event which will take place at the "end of times" with the second coming of Christ, but also as something that takes place now. The final judgment is not only a thing of the future, but is also something of the present. In this regard John $5: 24-25^{13}$ is a good example: "I tell you the truth, whoever hears my word and believes him who sent me has eternal life and will not be condemned; he has crossed over from death to life. I tell you the truth, a time is coming and has now come when the dead will hear the voice of the Son of God and those who hear will live" (emphasis by the author). It should thus be clear that the New Testament does not make a clear distinction between the present and the future. What we expect in future, is already a reality in the now; and what is already a reality in the now will be fully revealed in future (cf Pannenberg 1993:649654).

A counter-argument would be that the above-mentioned biblical texts deal with faith and not with morality. I wish to make two remarks in this regard. Firstly, it is not possible to draw a clean line between faith and morality because these two aspects of religion are inseparable. When these text verses deal with faith, the morality of the believer is definitely not excluded. Secondly, Christians can never assume that there is no relation between their moral actions and God's judgment in the present. Theologians like Martin Luther (WA 10, I, 1, 90, 8; 10, I, 2,137-138; cf Honecker 1990:133-136;

\footnotetext{
${ }^{13}$ Also Jn 6:47-54; 8:12. (However in Jn 12:47-48 exactly the opposite idea is encountered. In this instance the judging of disbelief will take place at the "end"). Rudolf Bultmann (1969; 1975:38-55, 138-155) played a leading role in determining this relationship between the now and the future. He emphasized the reality of the eschaton in the decision of faith here and now. Pannenberg (2000:277-282), however, correctly warns against diluting the final events of history. Africans in particular would appreciate the warning against the destruction of the unity between individual and humanity.
} 
Slenczka 1999:7-8), have explained this reality in terms of the Christian notion of "conscience". Luther stated that our "conscience" has to do with the knowledge that we constantly live before the sight of God who judges our moral behavior (and for this reason we do not live etsi Deus non daretur). Therefore, the argument that the final judgment gives people the freedom to lead immoral lives is without any substance. A person who is conscious of the fact of a life coram Deo, lives with the knowledge that this God is the ultimate judge of all moral behavior.

There is, however, a more important issue that requires our attention. The Bible does not primarily concern itself with the future and the end of history (futurum), but with the One who is coming in future (adventus - cf Moltmann 1995:40-44; Bayer 2003:303-304). In this regard reference is made to Matthew 24:36-44 (dealing with the unknown day and hour) Matthew 25:113 (the parable of the Ten Virgins) Revelation 22:12-16 (the Alpha and the Omega coming to judge). One should therefore not focus too strongly on the question of when the judgment is going to take place, but rather on the question of who is coming to judge. The One who judges and who is going to judge is Jesus Christ, our Saviour. Our Saviour expects us to live according to high moral standards - the highest conceivable standards! Our Saviour will, however, judge us with grace and mercy. The question therefore is: Do grace and mercy encourage people to live responsible lives? As Calvinists we would tend to answer in the affirmative. The third part of the Heidelberg Catechism dealing with morality, is based on the presupposition that the justified shall live responsible lives out of gratitude for their salvation (cf Q \& A 86 in particular).

\subsection{Images of the final judgment}

One of the major problems with the notion of the "final judgment" is the terrible images people have of this event. In addressing this issue, I want us to look anew at the biblical images of the final judgment. I want us to look anew at the biblical images of the final judgment. The biblical images of this event are far removed from the terrible pictures of suffering that people associate with the final judgment. The biblical images of this notion portray events that are indeed very dear to African social life. I am convinced that Africans would not have insurmountable problems in accepting the notion of the final judgment, once they look at these images with new eyes.

\subsubsection{Joyfully expecting Christ as our judge}

The image of the final judgment as a "day of fear"14 is one-sided. The same applies to the image of the Judge. The authors of the Heidelberg Catechism

\footnotetext{
${ }^{14}$ Wolfgang Amadeus Mozart thus described the final judgment in his famous Requiem (a composition composed for and performed at the funeral of an important person).
} 
(Q \& A 52) realized it and decided to rather deal with this notion in terms of providing comfort to believers. It is thus formulated as follows: "In all my distress and persecution I turn my eyes to the heavens and confidently await as judge the very One who already stood trial in my place before God and so has removed the whole curse from me ... me and all his chosen ones he will take along with him into joy and the glory of heaven". The perspective in the Catechism was formulated with biblical images in mind. The biblical images of the final judgment are images of joy and celebration, because this event is about salvation amid perdition. The following text verses come to mind:

- The image of the wheat which will not be destroyed together with the weeds, and similarly that of the believers who will not be destroyed with the evil of this world (Parable of the Weeds - Mt 13:24-30; 36-43).

- The image of the net and the fish and similarly that of the righteous who would not be thrown into the fiery furnace/or the righteous who would be caught by the angels (Mt 13:47-50).

- The image of the wedding banquet (Mt 22:1-14; $25: 1-13$ ) as a joyful occasion.

In summary: The day of judgement is a day of celebration and festivity ${ }^{15}$ (which is so important in Africa). Believers should understand this as a day of comfort and joy. Believers must see this event as the final step to salvation and that it is a graceful blessing not to be part of a self-destructive world. If this message comes across in our teaching, it should be well received in Africa.

\subsubsection{Communication and togetherness}

In my opinion one of the reasons why Africans experience difficulties with this notion, is that missionaries and pastors have created an image of the final judgment as being an event during which lonely individuals are confronted with their transgressions written down in a book. ${ }^{16}$ This image is far removed

\footnotetext{
${ }^{15}$ Celebration and festivity are at the heart of African Christianity. In a book of historical importance, Magesa (2004:197-221) recently stated, that "ritual celebration" forms the heart of African "spirituality".

${ }^{16}$ It is understandable that illiterate people in particular would experience difficulties in conceptualizing a "book". However, the "book" metaphor is to a certain extent indicative of the unity of time and eternity and the continuity of this life and life after death. God's judgement ensures this unity and continuity (Slenczka 1999:15).
} 
from the anthropological realities of the African continent. According to Steve Biko (2004:45-47), one of the outstanding characteristics of Africa is the joyful communication of groups at meals and feasts. Africans like to talk to each other - but not always with the aim of solving problems (as Westerners tend to do). They want to sing and dance together as a group. They want to share in the spirit of "ubuntu"; the spirit of mutual caring and sharing; the spirit of simply being with others in one's community and of one's extended family (cf Schutte 2001; Geyke 2002; Ramose 2002; Broodryk 2002 on the notion of "ubuntu").

Another reason why Africans find it difficult to embrace the notion of the final judgment, is because of the emphasis placed on judgment as the final division among people. ${ }^{17}$ This judicature is also far removed from the African understanding of a judicial process. According to Laurenti Magesa (1998:2735) the aim of judgments in common and civil law in Africa is to ensure concurrence and reconciliation. It wants to restore harmony and good relationships. Africans will even postpone a judgement in the hope of people reconciling their differences.

Many biblical images of the final judgement are images of the community of saints (one big united ensemble of family and friends) celebrating their salvation at meals, wedding banquets and through choir singing. In sermons on the final judgment, we should thus rather concentrate on the following aspects:

- The coming of the final judgment as the coming of a great wedding banquet (Mt 25:1-13; Lk 14:15-23)

- The final judgment as a gate for believers and the obedient opening up to a life in a new city/a new society (Rv 21 ).

- The final judgment as an event of choir singing (Rv 19).

In summary: The Bible depicts the final judgment as a joyful wedding. At weddings, family and friends come together to eat, sing and enjoy good

\footnotetext{
${ }^{17}$ I agree with Karl Barth that it is in any event wrong to focus on the idea of a final separation of people. The final judgment is not so much about a separation of people, but about a separation of the evil that stands between people. It is people's sin and evil which have to be left outside the gates of heaven - and that is what judgment is. Barth understands this judgment as grace. Grace means that people's deeds which created division among them, shall be removed. The association of people with their deeds will disappear. The oppressed will no longer fear the deeds of the oppressor - not even as a memory. The oppressor's evil deeds will no longer determine his identity. For a new creation to come into being, a final judgment is necessary - and this is grace; the grace that enables enemies to share communion without the burden of the deeds of the past (cf Etzelmüller 2005:275-276).
} 
company. The Groom invites everyone to join in these festivities. Those on the outside have chosen ${ }^{18}$ to be there. They cannot blame the Groom.

\subsubsection{The Final Judgment: Justice at last!}

Africa's history is a bloody history. It is a history of oppression, aggression, war, revenge and counter-revenge, homicide and genocide. What people, families and nations ultimately long for, is justice. They long for a form of justice where the culprit does not triumph over the victim. Does ultimate justice, however, exist? Yes, it does, but then God should provide this justice. Many people agree with the German poet Friedrich Schiller who said that "the world history is the judgment of the world". They believe that a judgment outside or beyond human history cannot be expected. According to them, we simply have to trust history that justice will prevail. Others agree with G W F Hegel's view that the dialectical process of history, in terms of which God reveals himself, would eventually result in a situation of justice. Neither pessimism nor optimism about world history provides a solution to the problem of justice (cf Jüngel [2003] on Schiller and Hegel). Nor would the International Criminal Court offer the solution. In the quest for ultimate justice God and his final judgment provide the only solution (cf Theissen 2003 for all the reasons):

- Acts 17:31 "For he has set a day when he will judge the world with justice by the man he has appointed. He has given proof of this to all men by raising him from the dead."

- 2 Ti 4:8 "Now there is in store for me the crown of righteousness, which the Lord, the righteous Judge, will award to me on that day ... and not only to me, but also to all who have longed for his appearing."

In a report emanating from Kenya it comes to light that thousands of people learnt more about Christ's justice-bringing judgment from the Marxist writer Ngugi wa Thiong'o, than they did from Anglican and Presbyterian

\footnotetext{
${ }^{18}$ It could be argued that "individual freedom of choice" is a typical "Western" idea which is foreign to Africa. Should this be the case, we could approach the issue in the following way: sacrificial negligence and ceremonial absence are regarded as serious moral offences in Africa. Africans accept that failure in respect of these duties have serious religious consequences, such as a moratorium of divine blessings being placed on offenders. By using this example as argument, one could steer clear of the concept of "individual choice" and concentrate on the familiar ideas of ritual duty and negligence.
} 
missionaries. As people who were looking for ultimate justice they could discover the importance of the notions of the "New Jerusalem" and the "last judgment" through his writings (cf Anonby 1997 for a report on this great novelist, playwright and essayist). We should not make the same mistake the clergy in Kenya made. We must tell our people about the good news of Christ's restorative justice.

In this regard it is useful to refer to Jürgen Moltmann (1989:359-363; 1995:278-284). He teaches that the final judgment is a judgment that creates justice. According to him, Christ judges in adherence to a "resocializing penal code" (Resozialisierungsstrafrecht). He argues that the original idea of God's judgment was to create justice for the sufferers of injustice in Israel. The original hope was that God would help the powerless in their distress. Those who experienced injustice would experience the justice of God's care, while at the same time, the transgressors would experience the justice of his forgiveness. In this way, $\mathrm{He}$ as Judge creates the conditions for peace among people (Ps 94; 96; 99; Is 2:2-5; Jn 3:17). This reconciling idea of justice should appeal to the African mind.

\section{THE FINAL JUDGMENT AS A JUDGMENT OF OUR WORKS}

As you will recall, Donders blamed Christian eschatology for the moral chaos in Africa. His problem with our eschatology is that our God does not immediately punish people for their transgressions and immoral behaviour. In defending Christian eschatology, I wish to make four remarks. Firstly, that the final judgment at or after death is a more radical impulse for responsible morality than is the judgment of the ancestors in the here and now. Secondly, this religion is not only intolerant of moral transgressions, but also encourages social responsibilities. My third argument is based on God as the final judge. I am convinced that when people realize that no human being, but God is the final judge, they would be inclined to live more responsible lives.

\subsection{Judgment and punishment of moral behaviour}

Most traditional Africans believe the ancestors are the watchdogs over morality and punish people for bad moral behaviour. They however only do so in extreme cases. They believe for instance that the ancestors would severely punish people for serious sexual transgressions such as incest and 
homosexuality, but not for something like fornication ${ }^{19}$ (Magesa 1998:145146).

Do traditionalists see the Supreme Being also as judge of moral behaviour? There is no consensus in Africa on this matter. The Azande, Akan and Swazi peoples, for instance, do not see moral offences as offences committed against God. According to them, God has nothing to do with morality. Moral offences are offences committed only against the ancestors. Not everyone would agree with the viewpoint that God has nothing to do with morality. Most traditional Africans believe that God punishes people for moral offences. He punishes them in the form of calamities of all kind. When certain taboos are transgressed, he could even punish offenders with death. These punishments affect people, but only in this life. They do not expect God to punish people at or after death (Mbiti 1985:156, 207-211).

It is important for us as Christians to understand why traditional Africans (and with them, thousands of Christians who are influenced by Traditional Religion) do not value a judgment at or after death. Should we be able to produce a satisfactory thesis explaining this mystery, we could be in a better position to explain our faith to them. The following remark could perhaps bring some clarity in this regard. Traditional Africans do not draw a distinction between good and bad. Only when relationships are disturbed, would a certain act be seen as a bad act. If someone does something wrong in secret and it has no direct effect on other people, then this act would not be regarded as an offence. Therefore, secret sins or sins committed in secret do not exist as far as Africans are concerned. In ATRan act, a deed or a person is evil, because it was punished: It is not punished because it is evil ${ }^{20}$. An act in itself is never bad as such, and would therefore not be punished by God. Only when the consequences of the act are bad, would it be punished as an evil act (Mbiti 1985:43-45, 206-207, 213). I suspect this particular understanding of moral transgression could provide a possible explanation for

\footnotetext{
${ }^{19}$ The biblical message shares the views on incest and homosexuality, but not the view on fornication. In this regard, refer to: Eph 5:1-6: "Be imitators of God ... live a life of love ... there must not be even a hint of sexual immorality, ... or of greed ... No immoral, impure or greedy person ... has any inheritance in the kingdom ... because of such things God's wrath comes on those who are disobedient"; Col 3:5-6: "Put to death, therefore, whatever belongs to our earthly nature: sexual immorality ... evil desires ... Because of these the wrath of God is coming"; Heb 13:4: "Marriage should be honored by all, and the marriage bed kept pure, for God will judge the adulterer and all sexually immoral."

${ }^{20}$ This understanding of sin and judgment is not totally unchristian. Christians also believe that sin and evil become are revealed after it had been destroyed. The Germans discovered the inhumanity of their politics after both World Wars. Only a few theologians, such as Karl Barth, understood at the beginning of the wars that the Germans? were confronted with God's judgment, in the sense that God delivered them to the consequences of their own sin (cf Etzelmüller 2005:262).
} 
the absence of our notion of judgment in ATR and in African Christianity. The biblical understanding of moral transgressions and the punishment thereof is diametrically opposing the African view.

There is sufficient biblical evidence that the final judgment will be the disclosure and punishment of those wrongs committed in secret:

- Ec 12:13-14: "21 "Fear God and keep his commandments, for this is the whole duty of man. For God will bring every deed into judgment, including every hidden thing, whether it is good or evil."

- $\mathrm{Rm}$ 2:16: "This will take place on the day when God will judge men's secrets through Jesus Christ, as my gospel declares."

- 1 Cor 4:5: "Therefore judge nothing before the appointed time; wait till the Lord comes. He will bring to light what is hidden in darkness and will expose the motives of men's hearts. At that time each will receive his praise from God."

The question we have to answer is: Why should these perspectives on morality and judgment be good news to Africans? I can think of the following reason: Africa is a continent of secrets. Many aspects of social life are kept secret. Certain aspects of initiation ceremonies, love relationships, social punishment and burial rituals are often kept secret. Many people live and die in the knowledge that they will never know the truth about many happenings and events, such as the disappearance or death of their loved ones. Hope in the future revelation of the truth as far as people and events are concerned, could be comforting to many African people. We as South Africans, at least, have over the last decade come to know the special value of the close relationship between the revelation of truth and healing. ${ }^{22}$ Our political experience could be a vehicle for religious understanding.

The fact that God punishes - ultimately punishes - or punishes at or after death - should not be an obstacle to moral responsibility, but rather an encouragement for social responsibility. When it is known that God will

\footnotetext{
${ }^{21}$ There is a general view that this text, as well as Ecclesiastes 11:9, is a later gloss inserted by an Orthodox redactor, with the aims of making Qohelet acceptable to traditional Jewish believers and of ensuring its place in the canon (cf Braun 1973:151-152; Lauha 1978:209, 223; Beek 1984:133; Kaiser 1985:12, 122; Michel 1988:166-168). I would disagree with this viewpoint. I am of the opinion that Qohelet herewith introduces a new and important aspect of God's judgment which his tradition had overlooked.

${ }^{22}$ I am referring to the work of the Truth and Reconciliation Commission.
} 
eventually disclose secret immorality, people would in all likelihood be reluctant to carry out their evil ideas.

\subsection{The final judgment and social responsibility}

According to various text verses, the final judgment will not only be a judgment of our faith in Jesus Christ, but also a judgment of our works and deeds:

- 2 Cor 5:10: "For we must all appear before the judgment seat of Christ, that each one may receive what is due to him for the things done while in the body, whether good or bad."

- Heb 10:26-31: "If we deliberately keep on sinning after we have received the knowledge of the truth, no sacrifice for sins is left, but only a fearful expectation of judgment ... Anyone who rejected the law of Moses died without mercy ... How much more severely do you think a man deserves to be punished who has trampled the Son of God under foot ... For we know him who said: 'It is mine to avenge; I will repay' and again, 'The Lord will judge his people'. It is a dreadful thing to fall into the hands of the living God."

- Jas 12: "There is only one Lawgiver and Judge, the one who is able to save and destroy."

- 1 Pt 1:16-17: "Be holy, because I am holy. Since you call on a Father who judges each man's work impartially ..."

Prophesying in God's name, driving out demons and performing miracles will not be enough when it comes to the final judgment. One also needs to do God's will. To be able to do God's will one has to become a good tree bearing good fruit. Only by bearing good fruit, will one survive the final judgment (cf Mt 7:15-23 - a tree and its fruits). What then are the fruits needed to pass the final judgment? Clearly diaconical works born out of love, amongst others. We read in Mt 25:31-46:

When the Son of Man comes in his glory ... he will separate the people one from another as a shepherd separates the sheep from the goats. He will put the sheep on his right and the goats on his left. ... They will also answer, 'Lord, when did we see you hungry or 
thirsty or a stranger or needing clothes or sick or in prison, and did not help you?' He will reply: '... whatever you did not do for one of the least of these, you did not do for me.'

Jesus makes it very clear that those who are not willing to help those in need, will not see the future kingdom (cf Lk 16:19-31 - The parable of the rich man and Lazarus). When we as Christians know that we could jeopardize our own salvation through a lack of diaconical works, how could someone then blame Christian eschatology for the moral degeneration and social collapse of the continent? Does the problem not lie somewhere else, at the core of African social and moral fibre, namely in "ubuntu"?

Ubuntu (cf Broodryk 2002; Ramose 2002) means a lifestyle of collective sharing and social caring. The question, however, is this: Does the ethics of "ubuntu" concern itself with the rest of society? Does it concern itself with others (those who do not belong to my group) and enemies? As far as I know, it is not concerned about "others" and foes. Is this not perhaps the big problem in Africa?

The works and the deeds, by which God in Christ will judge the world, all have to do with love. The love Jesus had in mind, involves more than the love for one's own family. It involves love even for one's enemy (Mt 5:43-48; Lk 10:25-37). How can someone blame Christianity for the social degeneration of this continent when it has radical views on social responsibility?

\subsection{The judgment of people and the judgment of God}

The fact that the final judgment - the last word about my life - vests with God, should be comforting to Africans. In view of the fact that they (as is the case with all other people ${ }^{23}$ ) are constantly on trial and have to bear with negative judgments from others (in spite of the warning of Mt 7:1-5), this notion should be appealing to them. Allow me to explain this notion in a very concrete way. Many outsiders judge Africans in a negative way. They accuse them of immorality, laziness, incompetence et cetera. These negative moral judgments are very hurtful. The comfort of the final judgment, as the "judgment of appeal" (Lochman 1993:82), is that the moral judgment of others,

\footnotetext{
${ }^{23}$ One of the consequences of the European Enlightenment which manifested in the secularization of the theodicy-problem, is that people from the "First World" are constantly on trial. Since they retired God on pension, they have to justify their existence in the light of the still imperfect world. They stand trial before public opinion. They are forced by judgment to subject themselves to public opinion and public demands. Those who dare not to subject, are ungracefully condemned (Bayer 1991; Lochman 1993:80-81; Slenczka 1999:4).
} 
is not the final word on Africa. The final word on African humanity will come from Christ, and it would be a word of grace:

- Acts 10:42: "He commanded us to preach to the people and to testify that he is the one whom God appointed as judge of the living and the dead."

- Romans 12:19: "Do not take revenge, my friends, but leave room for God's wrath, for it is written: 'It is mine to avenge; I will repay', says the Lord."

- Romans 14:10: "You then, why do you judge your brother? Or why do you look down on your brother? For we will all stand before God's judgment seat."

The fact that the opinions of others will not be the final word about the African existence, should be experienced as absolute grace. The fact that the final judgment on our worthiness as humans belongs to Jesus Christ (1 Cor 2:15), should fill Africans with gratefulness. Africans must, however, also learn not to live by their self-judgment (1 Cor 4:3-4). Real freedom is freedom from the captivity of judgments by others and of the self. The struggle for freedom in Africa will end when Africans learn to trust God's judgment and to abandon the quest for human acceptability. ${ }^{24}$

\section{THE FINAL JUDGMENT AS A JUDGMENT OF OUR FAITH}

At the final judgment not only our deeds and cultural and social failures will come under the spotlight, but also our faith. Our acceptance or rejection of Jesus Christ will determine our fate after death. We will either be with God forever, or we will be excluded from his presence forever:

- Jn 3:18: "Whoever believes in him is not condemned, but whoever does not believe stands condemned already ...".

- Jn 5:24: “ ... whoever hears my word and believes him who sent me has eternal life and will not be condemned ...".

\footnotetext{
${ }^{24}$ This is what Luther tried to teach the people of his time (cf Bayer 2003:301-303).
} 
- Jn 12:47-48: "For I did not come to judge the world, but to save it. There is a judge for the one who rejects me and does not accept my words; that very word which I spoke will condemn him at the last day."

Northern Christianity has great difficulties with this aspect of the gospel. The concern about the fate of others creates uneasiness about this message. In Germany, for instance, the churches associated with the Union of Lutheran Churches in Germany (VELKD) prefer not to use a text such as Mark 16:16 (referring to the condemnation of those who do not believe and are not baptized ) in their baptismal formula any longer, the reason being that people no longer want to understand the gospel as the message of redemption from God's judgment (Slenczka 1999:13).

Africans are also uncomfortable with the idea that God could exclude certain people from his kingdom. The question that Africans will immediately ask is: What about our ancestors who did not believe in Christ? Are they condemned forever? Is the notion of the final judgment not intrinsically unfair, because they could not have known Christ? Is this not a blasphemous judgment? They became ancestors because of their virtuous contribution to society. Is it conceivable that God would reject people who fulfilled the highest moral duties of society, simply because they could not hear the message of God's revelation in Christ? This is a serious theological dilemma which has to be dealt with. If the African ancestors are to be excluded from God's kingdom, then Africans will adhere to their beliefs about the "world of the ancestors" and neglect Christian eschatology. ${ }^{25}$ Should we argue that everyone will automatically become part of God's kingdom, then there is no need to leave Traditional Religion and no reason why Africans should become Christians. If the argument is that eternal salvation is not a relevant theme ${ }^{26}$ to Africans, then African theology will work with a concept of salvation based on a very small canon within the canon.

There is no "African solution" to this problem. This is a basic problem associated with Christian eschatology. African ideas can, however, guide us looking for solutions in a direction which would appeal to the African mind. The biblical texts lead us into at least two ${ }^{27}$ possible directions. The one

\footnotetext{
${ }^{25}$ An African Christianity in which African ancestors are excluded, is an unrealistic enterprise (cf for instance Bediako 1997).

${ }^{26}$ In a much-needed effort to emphasize the materialistic nature of Christian salvation, African theologians tend to follow the easy route by neglecting the difficult discourse on "eternal salvation" (cf Kwenda 1999; Brand 2002).

${ }^{27}$ The limitations of this article do not allow us to go into the teachings of the "purgatory" and the annihilatio. The latter in particular would make sense in Africa (cf Härle 2000:620-623).
} 
direction leads to a "twofold outcome of the final judgment" (Mt 7:13-14; 22:14; 25:31-46; Jn 3:36, 5:24; Mt 7:21-23, 12:36, 16:27; Jn 5:29; Rm 2:5-10; 1 Cor 3:13-15; 2 Cor 5:10), whilst the other leads to the so-called "universal homecoming" (apokatastasis panton) or the "reconciliation of everyone" or the "redemption for everyone"28 (Ac 3:21; Rm 11:32; 2 Cor 5:19; Col 1:15-20; 1 Tt $2: 4)$.

The history of theology teaches that the church always tended to choose in favour of the "twofold outcome". ${ }^{29}$ Martin Luther (WA 26, 509, 1318) presents us with a classic example of the orthodox view. He is convinced that the overwhelming message of the Bible has to do with the following: The belief in a general resurrection, a final judgment according to faith and deeds, the hope that the righteous will live for ever with Christ and that the wicked and the evil will perish for ever with the devil and his angels. The mere fact that the "devil" could not and should not share in God's salvation, makes a decision in favour of a "twofold outcome" self-evident and the acceptability of the "homecoming" theory almost impossible.

This belief, however, poses many difficulties. Faith as a criterion for God's judgment is problematic. Will only those be saved who believed at the time of the last moment, or will those who believed at one stage of their lifetime be saved? What would God expect us to believe? What would the expected package be? The image of man in this theory is problematic. Would only people who are intellectually capable of answering to God's calling be saved? Would the mentally handicapped be excluded from the kingdom? The image of God as the God of love then becomes problematic. On the one side, it is unthinkable that love could exclude, but on the other side, would a God who does not exclude evil be a loving God? Should one suspend God's wrath in eschatology, one should then also suspend it in soteriology - with the consequence of having to suspend the cross of Christ.

As far as the African problem with regard to the fate of the ancestors is concerned, it would appear as if the theory of the "universal homecoming" would provide a better solution. In this theory the emphasis falls on God's will to save everyone and on his grace, mercy and unending love. One aspect of this teaching would in particular appeal to the African mind, namely God's will to create communion with his creatures at a feast (Is 25:6-8; Rv 7:17, 21:4, and Lk 14:16-24, 15:20-32). His will is to include everyone and not to exclude

\footnotetext{
${ }^{28}$ The term "redemption for all" (Allerlösung) as proposed by J Janowski (2000) is a better term than the classical "reconciliation for everyone (Allversöhnung). It includes the cosmological dimension of salvation.

${ }^{29}$ This consensus is clearly formulated in the Athanasianum. Important decisions in this consensus-building process were those against Origen and the Anabaptists (cf Härle 2000:611-612 for references).
} 
anyone. Within this framework of thinking, the Last Judgment could be explained as a declaration of our suitableness for communion with God. We become "suitable" because of his grace, which is to be understood as the forgiveness of our unwillingness to have a relationship with God. In this sense, grace as judgment, creates communion - the final will of God (Stümke 1996:105-124).

To argue that eternal punishment cannot be the final will of the God of love and that God's unlimited love even implies a willingness to save the "devil" from hell and to argue that no one should feel uncomfortable in the knowledge that others would not be saved, would be respectable - but is that the full biblical picture? Can one totally exclude man from the salvation process? If nothing is expected of man, then religion as such becomes superfluous. If God could not be affected by the rejection of His love, then $\mathrm{He}$ could not be a "human God". Thus, the spirit of the gospel tends to favour the teaching of the "twofold outcome". With Barth (Slenczka 1999:16), we should therefore say, "The one who does not believe in the universal homecoming is an ox; the one that however preaches this is a donkey". There will always be a tension between sola fide and sola gratia, the love of God and the wrath of God, between hope and dogma. Our concern to find answers as far as the fate of the ancestors is concerned, will be based on speculation. The God of the Bible is a hidden God. His ultimate will remain obscured to us. We can only hope that his never-ending grace will ultimately prevail (Schwarz 2000:396-397). Whether God will save the African ancestors, we do not know. We can only speculate. The hope that the ancestors would be saved cannot become part of Christian teaching, but should remain part of the Christian prayer. The only sensible thing we could say is thus: We will pray that Christ, through his grace and mercy, will include them in his kingdom. No other statement will solve this dilemma.

\subsection{Eternal punishment?}

With reference to Steve Biko's statement that "hell" or eternal punishment is an unacceptable notion to the African mind, the question is: Is the idea of eternal punishment unknown to Africans and should we talk about it in African theology?

I do not agree that the idea of an eternal punishment is unbeknown and unacceptable to Africans. Let me give one example: Many informants have assured me that people with unacceptable lifestyles will never enter the world of the ancestors. Only people whose lifestyles were exemplary will become ancestors. Hence - a final judgment with eternal consequences also forms part of Traditional Religion. Allow me to re-iterate this by using a more specific 
example: The Ndebele, for instance, did (do?) not bury unmarried women (a serious moral transgression, because they did not comply with the moral duty of procreation) in a proper manner. By consequence, they will not share in the world of the ancestors - or in other words, they will experience eternal death (cf Mbiti 1985:152). Bearing this in mind, we can approach the theological problem with more confidence.

Christian theology uses the concept "hell" when referring to eternal damnation. The question is whether African theology should speak about "hell" since it has become an undesirable theme in Northern Christianity.

One reason for their reticence is their discovery that "hell" was not a central topic in early Christianity. They concentrated on the positive message of salvation. Only since emperor Constantine (280-337 CE) did the final judgment become important. "Hell" was presented as a warning of damnation for those who did not want to share in the empire's official religion. The same tactic was used by the Counter-Reformation. They tried to scare the Protestants who rejected the teachings of the Roman Catholic Church. In the modern world of toleration and dialogue, there is no place for such a notion. Another argument is that people no longer fear the "deepest darkness" (2 Pt 2:17), "the outer darkness", the "weeping and gnashing of teeth" (Mt 22:13) and an "eternal fire" (Mt 25:41). Theologians therefore argue that it would be unwise to talk about eschatology in mythological terms in the "First World".

Despite the fact that not many church members believe in a place called hell and that theologians prefer not to mention it, the word remains part of public vocabulary. We frequently encounter it in movies and pop music. What is the reason for it? Is it not perhaps because "hell" will always remain an intrinsic part of every religion?

The problem with the talk about "hell", is that we make it a problem of cosmological topography, whereas "hell" is rather a problem of our belief and unbelief. The Russian thinker Nikolaj Berdiajew (1930:370-374) is most probably correct in stating that "hell" is not a personal or communal problem concerning eternal salvation. It is rather an "ethical problem". The idea of "hell" is not rooted in God's righteousness, but in our freedom. God will not force people into "hell" (or paradise). "Hell" is a metaphor for the psychological anguish rooted in our choice against God. "Hell" is what we bring upon ourselves by rejecting the gospel, namely the unending uncertainty about our end. It is therefore a metaphor of the tragedy of human freedom. Hans Schwarz (2000:402-403) is therefore correct in stating that images of "hell" express 
... the reaction to the disclosure and finalization of the discrepancy between one's eternal destiny and one's realization of this destiny. They express the anguish of knowing what one has missed without the possibility of ever reaching it. They witness to a state of extreme despair without the hope of reversing it ... Hell is [therefore] of no ultimate concern .... It serves only as an admonition to reach our eternal destiny.

Africans do not have to fear the God of the Bible and his "hell". The "hell" they should fear, is the "hell" they themselves create after having listened to the gospel. Whether their ancestors will remain in "hell", is a question theologians will not solve. Our task lies in hope and prayer. Nothing more!

\section{FINAL WORD}

The final judgment is an important aspect of the biblical message that should not be neglected. Africans should not emulate their white counterparts in their negligence of this notion. Despite a lack of theological tradition in this regard in Africa, ample possibilities exist to introduce this notion to African Christianity in a positive way. I have given some ideas. I invite Africans to critically evaluate these proposals and to make their own suggestions.

\section{Works consulted}

Anonby, J 1997. Images of Christ in East African literature: The novels of Ngugi wa Thiong'o, in Porter, S e a (ed) Images of Christ: Ancient and modern, 239258. Sheffield: Sheffield Academic Press.

Bayer, O 1991. Das Letzte Gericht als religionsphilosophischen Problem. NZSTh 33, 199-210.

Bayer, O 2003. Martin Luthers Theologie: Eine Vergegenwärtigung. Tübingen: Mohr.

Bediako, K [1995] 1997. Christian religion and the African world-view: Will ancestors survive?, in Christianity in Africa: The renewal of a non-western religion, 210230. New York: Orbis Books.

Beek, M 1984. Prediker, Hooglied. Nijkerk: Callenbach. (De Prediking van het Oude Testament.)

Berdiajew, N 1930. Die Philosophie des freien Geistes: Problematik und Apologie des Christentums. Deutsch von von Walter, R. Tübingen: Mohr.

Biko, S 2004. Steve Biko: I write what I like: A selection of his writings, ed by A Stubbs. Johannesburg: Picador Africa.

Brand, G 2002. Speaking of a fabulous ghost: In search of theological criteria, with special reference to the debate on salvation in African Christian theology. Frankfurt: Peter Lang. (Contributions to Philosophical Theology, Vol 7.)

Braun, R 1973. Kohelet und die frühhellenistische Popularphilosophie. Berlin: De Gruyter. (Beiheft zur ZAW 130.) 
Broodryk, J 2002. Ubuntu: Life lessons from Africa. Pretoria: Ubuntu School of Philosophy.

Bultmann, R [1966] 1969. The eschatology of the Gospel of John, in Faith and understanding, vol I, 165-183, tr by L Smith. London: SCM.

Bultmann, R [1957] 1975. The presence of eternity: History and eschatology; The Gifford Lectures, 1955. Westport: Greenwood Press.

Donders, J 1985. Non-bourgeois theology: An African experience of Jesus. New York: Orbis Books.

Etzelmüller, G 2005. Realistische Rede vom Jüngsten Gericht: Erkenntnisse im Anschluss an Karl Barth. EvTh 65(4), 259-276.

Gyekye, K 2002. Person and community in African thought, in Coetzee, P H \& Roux, A P J (ed). Philosophy from Africa: A text with readings, $2^{\text {nd }}$ ed, 297-312. Oxford: Oxford University Press (SA).

Hammond-Tooke, D 1993. The roots of black South Africa. Johannesburg: Jonathan Ball.

Härle, W [1995] 2000. Dogmatik: Zweite, überarbeitete Auflage. Berlin: De Gruyter.

Heyer, F 1999. Erwartung des Jüngsten Tages - Sektensache? EvTh 59, 457-458.

Honecker, M 1990. Einführung in die Theologische Ethik: Grundlage und Grundbegriffe. Berlin: De Gruyter.

Janowski, J 2000. Allerlösung: Annäherungen an eine entdualisierte Eschatologie. Neukirchen-Vluyn: Neukirchener Verlag.

Jüngel, E [2001] 2003. "Die Weltgeschichte als Weltgericht" aus theologischer Perspektive, in Ganz werden: Theologische Erörterungen, V, 323-344. Tübingen: Mohr.

Kaiser, O 1985. Der Mensch unter dem Schicksal: Studien zur Geshichte, Theologie und Gegenwartsbedeutung der Weisheit. Berlin: De Gruyter.

Kaiser, O 2003. Der Gott des Alten Testaments: Theologie des Alten Testaments.

Teil 3. Jahwes Gerechtigkeit. Göttingen: Vandenhoeck. (UTB 2392.)

Kato, B 1975. Theological pitfalls in Africa. Kisumu: Evangelical Publishing House.

Kwenda, C 1999. Affliction and healing: Salvation in African religion. JTSA 103, 1-12.

Lauha, A 1978. Kohelet. Neukirchen-Vluyn: Neukirchener Verlag. (BKAT XIX.)

Lochman, J 1993. Angst vor dem Jüngsten Gericht? ThZ 49(1), 77-88.

Lohse, B 1995. Luthers Theologie in ihrer historischen Entwicklung und in ihrem systematischen Zusammenhang. Göttingen: Vandenhoeck.

Luther, M 1833-. WA = D. Martin Luthers Werke: Kritische Gesamtausgabe: Weimarer Ausgabe. Weimar: Bohlaus.

Magesa, L [1997] 1998. African Religion: The moral traditions of abundant life. New York: Orbis Books.

Magesa, L 2004. Anatomy of inculturation: Transforming the church in Africa. New Yourk: Orbis Books.

Maluleke, T 1997. What Africans are doing to Jesus: Will he ever be the same again? in Du Toit, C (ed), Images of Jesus, 185-205. Pretoria: UNISA.

Mbiti, J [1970] 1975a. Concepts of God in Africa. $1^{\text {st }}$ Paperback ed. London: SPCK.

Mbiti, J 1975b. Introduction to African religion. Oxford: Heinemann.

Mbiti, J [1971] 1978. New Testament eschatology in an African background: A study of the encounter between New Testament theology and African traditional concepts. London: SPCK.

Mbiti, J [1969] 1985. African religions and philosophy, 11th ed. London: Heinemann. 
Michel, D 1988. Qohelet. Darmstadt: WBG. (Erträge der Forschung Band 258.)

Miggelbrink, R 2002. Der zornige Gott: Die Bedeutung einer anstößigen biblischen Tradition. Darmstadt: WBG.

Moltmann, J 1989. Der Weg Jesu Christi: Christologie in messianischen Dimensionen. München: Kaiser.

Moltmann, J 1995. Das Kommen Gottes: Christliche Eschatologie. München: Kaiser.

Müller, K \& Ritz-Müller, U 1999. Soul of Africa: Magical rites and traditions. Cologne: Könemann.

Niebuhr, R 1959. The kingdom of God in America. New York: Harper.

Nyirongo, L 1997. The gods of Africa or the God of the Bible?: The snares of African traditional religion in Biblical perspective. Potchefstroom: IRS. (Series F2. No 7.)

Obengo, T 1997. The role of the ancestors as guardians of morality in African traditional religions. Journal of Black Theology in South Africa 11, 44-63.

Pannenberg, W 1993. Systematische Theologie, Band 3. Göttingen: Vandenhoeck.

Pannenberg, W [1995] 2000. Die Aufgabe christlicher Eschatologie, in Beiträge zur Systematischen Theologie, Band 2: Natur und Mensch - und die Zukunft der Schöpfung, 271-282. Göttingen: Vandenhoeck.

Peters, A 1967. Kirche und Welt im Lichte des eschatologischen Richters- und Erretterhandelns Gottes. (NZSTh 9, 275-313.)

Ramose, M 2002. African philosophy through ubuntu. Harare: Mond Books.

Sauter, G 2004. Rechenschaft über die Hoffnung. VuF 49, 72-97.

Shutte, A 2001. Ubuntu: An ethic for a new South Africa. Pietermaritzburg: Cluster Publications.

Schwartz, H 2000. Eschatology. Grand Rapids, MI: Eerdmans.

Slenczka, R 1999. Der doppelte Ausgang des Endgerichts und die verheißene selige Schau Gottes. KuD 45, 2-20.

Stümke, V 1996. Befreit zur Gemeinschaft: Gedanken zum Jüngsten Gericht. NZSTh 38(1), 97-128.

Sundermeier, T [1988] 1990. Nur gemeinsam können wir leben: Das Menschenbild schwarzafrikanischer Religionen. 2. Aufl. Gütersloh: Mohn. (GTB 784.)

Theissen, H 2003. Nur der Richter kann Heiland sein: Zur Gerichtslehre aus Anlass der Errichtung des Internationalen Strafgerichtshofes. NZSTh 45(2), 170-207.

Van der Walt, B 2003. Understanding and rebuilding Africa: From desperation today to expectation for tomorrow. Potchefstroom: Institute for Contemporary Christianity in Africa.

Van Rooy, J A 1999. The Christian gospel as a basis for escape from poverty. In die Skriflig 33(2), 235-253.

Van Wyk, I W C 1996. Die prediking oor die eindoordeel. HTS 52(2\&3), 501-531. 